\author{
M.M. Bukenov, D.K. Koikelova \\ L.N. Gumilyov Eurasian National University, Nur-Sultan, Kazakhstan \\ (E-mail: dinara_dinara1982@mail.ru)
}

\title{
Modeling of a Static Incompressible Medium
}

\begin{abstract}
In the article mathematical modeling of the solution of the static Stokes problem is considered by solving the static problem of the theory of elasticity, with Hooke's law. We obtain estimates for the proximity of solutions of these problems under asymptotics, namely, when $\lambda \rightarrow \infty$, in this case the Poisson coefficient tends to 0,5 , which corresponds to an incompressible medium. Further, it was proved that the estimate of the proximity of the solutions of the problems considered as unimprovable in order of $\frac{1}{\lambda}$. This allows us to use previously differential schemes for the static problem of the theory of elasticity, as an approximate, it is obtained a method for solving the static Stokes problem on a sequence of grids.
\end{abstract}

Keywords: Incompressible medium, Hooke's law, stresses, deformations, displacements, Lame coefficients, the task of the Stokes, theory of elasticity, equilibrium equation, single-linked area.

In a bounded simply connected domain $D \subset R^{3}$ with a sufficiently smooth boundary $\gamma$, we will make a solution to the problem of the theory of elasticity for an incompressible medium that satisfies the equilibrium equation:

$$
\mu \triangle \bar{u}-\nabla p+\bar{f}=0, \quad x \in D,
$$

medium incompressibility condition

$$
\operatorname{div} \bar{u}=0, x \in D,
$$

displacement-strain relations

$$
2 \varepsilon_{i k}=\left(\frac{\partial u_{i}}{\partial x_{k}}+\frac{\partial u_{k}}{\partial x_{i}}\right), \quad i, k=1,2,3,
$$

equations of state of the environment

$$
\sigma_{i k}=-\delta_{i k} p+2 \mu \varepsilon_{i k},
$$

where $u(x)$ is the displacement vector, $p(x)$ is the pressure function, $f(x)$ is the vector of volume forces, $\varepsilon_{i k}(x)$ is the components of the strain tensor, $\sigma_{i k}(x)$ are the components of the stress tensor and the boundary condition

$$
\sum_{k=1}^{3} \sigma_{i k} n_{k}=0, x \in \gamma
$$

where $n_{k}$ is guides of cosines by norms to the boundary $\gamma$.

We also consider in the domain $D$ the formulation of the static problem of the theory of elasticity for a compressible medium and use following equations.

Equilibrium equations

$$
\mu \triangle \bar{u}^{\lambda}+(\lambda+\mu) \nabla \operatorname{div} \bar{u}^{\lambda}+\bar{f}=0, x \in D
$$

displacement-strain relations

$$
2 \varepsilon_{i k}^{\lambda}=\left(\frac{\partial u_{i}^{\lambda}}{\partial x_{k}}+\frac{\partial u_{k}^{\lambda}}{\partial x_{i}}\right), \quad i, k=1,2,3
$$

equations of state, Hooke's law

$$
\sigma_{i k}=\lambda \delta_{i k} \theta^{\lambda}+2 \mu \varepsilon_{i k}^{\lambda}
$$

In the formula (8) $\theta^{\lambda}=\sum_{j=1}^{3} \varepsilon_{j j}^{\lambda}, \lambda, \mu>0$ is Lame coefficients. 
Border conditions

$$
\sum_{k=1}^{3} \sigma_{i k}^{\lambda} n_{k}=0, x \in \gamma
$$

for the solvability of problems (6) - (9) the following conditions are necessary $[1,2]$

$$
\int_{D} \bar{f} d x=0, \int_{D} \bar{r} \times \bar{f} d x=0, \int_{D} \bar{u} d x=0, \int_{D} \operatorname{rot} \bar{u} d x=0,
$$

where $\bar{r}=r(x)$ is the radius vector of the point $x \in D$.

Earlier in the work, it was obtained an estimate for the proximity of the solution of problem (6)-(10) to the solution of problem (1)-(5) as $\lambda \rightarrow \infty$. Here we get this assessment in another way.

Let us denote $\bar{u}=\bar{u}_{0}+\frac{1}{\lambda} \overline{\mathrm{w}}$ where $\bar{u}_{0}$ is the solution of problem (1)-(5). By virtue of (6)-(10) and (1)-(5) we have:

$$
E\left(\bar{u}_{0}, \overline{\mathrm{v}}\right)+\frac{1}{\lambda} E(\overline{\mathrm{w}}, \overline{\mathrm{v}})+\int_{D} \operatorname{div} \bar{u}_{0} \cdot \operatorname{div} \overline{\mathrm{v}} d x+\int_{D} \operatorname{div} \overline{\mathrm{w}} \cdot \operatorname{div} \overline{\mathrm{v}} d x=\int_{D} \bar{f} \cdot \overline{\mathrm{v}} d x
$$

for an arbitrary function $\overline{\mathrm{v}} \in W_{2}^{1}(D)$

$$
E(\bar{u}, \overline{\mathrm{v}})=\frac{1}{2} \mu \int_{D} \sum_{i, j=1}^{3}\left(\frac{\partial u_{i}}{\partial x_{j}}+\frac{\partial u_{j}}{\partial x_{i}}\right)\left(\frac{\partial \mathrm{v}_{i}}{\partial x_{j}}+\frac{\partial \mathrm{v}_{j}}{\partial x_{i}}\right) d x .
$$

In (11) we add and subtract the expressions $\int_{D} p \operatorname{div} \overline{\mathrm{v}} d x$, as a result we get

$$
\frac{1}{\lambda} E(\overline{\mathrm{w}}, \overline{\mathrm{v}})+\int_{D} \operatorname{div} \overline{\mathrm{w}} \cdot \operatorname{div} \overline{\mathrm{v}} d x=-\int_{D} p \operatorname{div} \overline{\mathrm{v}} d x
$$

Assuming in $(12) \overline{\mathrm{v}}=\overline{\mathrm{w}}$, the estimate follows

$$
\frac{1}{\lambda} E(\overline{\mathrm{w}}, \overline{\mathrm{w}})+\|\operatorname{div} \overline{\mathrm{w}}\|^{2} \leq\|p\| \cdot\|\operatorname{div} \overline{\mathrm{w}}\| \leq \frac{1}{2}\|p\|_{L_{2}(D)}^{2}+\frac{1}{2}\|\operatorname{div} \overline{\mathrm{w}}\|^{2} .
$$

By virtue of the fact that

$$
\|p\|_{L_{2}(D)} \leq\|f\|_{W_{2}^{-1}(D)}
$$

then inequality holds true

$$
\frac{1}{\lambda}\|\overline{\mathrm{w}}\|_{W_{2}^{1}(D)}^{2}+\frac{1}{2}\|\operatorname{div} \overline{\mathrm{w}}\|^{2} \leq \frac{1}{2}\|f\|_{W_{2}^{-1}(D)}^{2} .
$$

After that we will finally get the next formula:

$$
\lambda\|\operatorname{div} \bar{u}\| \leq c \bar{f}_{W_{2}^{-1}(D)}
$$

Next, we estimate the higher derivatives of the solution of problem (6)-(10).

Theorem 1. Let $f(x) \in L_{2}(D), \gamma \in C^{2}$. Then, to solve the problem (6)-(10), the inequality is

$$
\|u\|_{W_{2}^{2}(D)}+\frac{1}{\varepsilon}\|\nabla \operatorname{div} \bar{u}\|_{L_{2}(D)} \leq c\|f\|_{L_{2}(D)}
$$

Evidence. If we follow to the work [3], from the smoothness condition for the boundary $\gamma$, it implies that there is a local change of variables $y=\psi(x)$, where $x \in \gamma$, let $\omega$ be a neighborhood of the point $x$ such that the piece of the boundary $\omega \bigcap \gamma$ becomes a piece of the hyperplane. Let denote through $\omega_{1}$ the small neighborhood of this point, which is at a positive distance from the boundary to the neighborhood $\omega$. Let $z(x)$ be a non-negative in $\bar{\omega}=\omega \bigcup \partial \omega$ a smooth function such that supp $z \subset \omega$ and $z(x)=1$ if $x \in \omega$. Finally, let us assume that the $y_{k}$ axis, $k=1,2, \ldots, n-1$ lies in the indicated hyperplane, and the $y_{n}$ axis is directed along the norms drawn to it. Solutions of problem (6) - (10) satisfy a neutral identity:

$$
E(\overline{\mathrm{u}}, \overline{\mathrm{v}})+\lambda \int_{D} \operatorname{div} \bar{u} \cdot \operatorname{div} \overline{\mathrm{v}} d x=\int_{D} \bar{f} \cdot \overline{\mathrm{v}} d x
$$


for any $\overline{\mathrm{v}}(x) \in W_{2}^{1}(D)$. Put in $(16) \mathrm{v}=z(x) \frac{\partial}{\partial y_{k}}\left(z(x) u_{y_{k}}\right)$, after integration by parts, evaluating the terms in the same way as in [4] we will have $\left\|u_{y_{k}}\right\|_{W_{2}^{1}(w)}^{2} \leq\|u\|_{W_{2}^{2}(D)} \cdot\|u\|_{W_{2}^{1}(\omega)}$, by virtue of (6)-(10), multiplying by $z(x) u_{y_{k}}$ integrating we get

$$
\lambda\left\|\frac{\partial}{\partial y_{k}} \nabla \operatorname{div} \bar{u}\right\|_{W_{W_{2}(D)}^{-1}} \leq M\left[\|f\|+\|u\|_{W_{2}^{2}(D)}^{1 / 2} \cdot\|f\|_{L_{2}(D)}^{1 / 2}\right]
$$

to estimate $\frac{\partial}{\partial y_{k}} \operatorname{div} \bar{u}$, we use the identity $\nabla \operatorname{div} \bar{u}=\operatorname{div}\left(\frac{\bar{f}}{\lambda+2 \mu}\right)$, which is obtained from (6), if we take the $\operatorname{div}$ by going to the variables, we express $\frac{\partial}{\partial y_{k}} \operatorname{div} \bar{u}$ through the remaining derivatives of the first and second order, which are already estimated. Then we get

$$
\left\|\nabla \frac{\partial}{\partial y_{k}} \operatorname{div} \bar{u}\right\|_{W_{2}(\omega)} \leq c\left[\|f\|+\|u\|_{W_{2}^{2}(D)}^{1 / 2} \cdot\|f\|_{L_{2}(D)}^{1 / 2}\right] .
$$

Let us suppose that the set $\omega$ is a finite cover $\bar{D}$, then in the last inequality on the left we can take the norm over the whole domain $D$. So we have

$$
\|u\|_{W_{2}^{2}(D)} \leq c\left(\|f\|_{L_{2}(D)}+\|f\|_{L_{2}(D)}^{1 / 2} \cdot\|u\|_{W_{2}^{2}(D)}^{1 / 2}\right) .
$$

The theorem is proved. Similarly we prove

Theorem 2. Let $f \in L_{2}(D)$, a domain $D$ is bounded, simply connected, with a sufficiently smooth boundary $\gamma$, then the estimate is valid.

$$
\left\|\bar{u}^{\lambda}-\bar{u}_{0}\right\|_{W_{2}^{2}(D)}+\left\|\lambda \operatorname{div} \bar{u}^{\lambda}-p\right\|_{W_{2}^{1}(D)} \leq c \cdot \lambda^{-1} .
$$

In the work [5], it was obtained an estimate for the proximity estimate for the solutions of problem (6)-(10) to the solution of problem (1)-(5).

$$
\left\|\bar{u}^{\lambda}-\bar{u}\right\|_{W_{2}^{1}(D)}^{2}+\left\|\lambda \operatorname{div} \bar{u}^{\lambda}-p\right\|_{L_{2}(D)}^{2} \leq c \cdot \lambda^{-2} .
$$

Let us show that this estimate is best possible in the order of the parameter $1 / \lambda$. for $\lambda$.

Theorem 3. An estimate of the proximity of the solutions of problems (6)-(10) and (1)-(5) is best possible

Evidence. Suppose the contrary, i.e.

$$
\left\|\bar{u}^{\lambda}-\bar{u}\right\|_{W_{2}^{1}(D)}^{2}+\left\|\lambda \operatorname{div} \bar{u}^{\lambda}-p\right\|_{L_{2}(D)}^{2} \leq c \cdot \lambda^{-(2+\alpha)} .
$$

where $\alpha>0$ is a constant, perhaps small enough, therefore we have:

$$
\begin{gathered}
\left\|\lambda \operatorname{div} \bar{u}^{\lambda}-p\right\| \geq\|p\|-\lambda\left\|\operatorname{div} \bar{u}^{\lambda}\right\| \\
\|p\| \leq \lambda\left\|\operatorname{div} \bar{u}^{\lambda}\right\|+\left\|\lambda \operatorname{div} \bar{u}^{\lambda}-p\right\| \leq c\left(\|\pi\|+\frac{\lambda}{\lambda^{1+\alpha / 2}}\right)
\end{gathered}
$$

Here $\pi=p-\lambda \operatorname{div} \bar{u}^{\lambda}$. In inequality (19), we wil pass to the limit as $\lambda \rightarrow \infty$; we can obtain it by virtue of (18). $\|p\|_{L_{2}(D)}=0$, i.e. $p=0$. Thus, for $\bar{u}$ and $p$ we get the following problem

$$
\begin{gathered}
\mu \triangle \bar{u}-\nabla p+\bar{f}=0, x \in D, \operatorname{div} \bar{u}=0, \quad p=0 ; \\
\sum_{k=1}^{3} \sigma_{i k} n_{k}=0, \quad x \in \gamma .
\end{gathered}
$$

As we see this contradicts our assumption, since the latter problem (21) is unsolvable (the initial problem $(1)-(5))$ is correct and it was required. 
References

1 Кобельков Г.М. Численное решение некоторых задач теории упругости: дис. ... канд. физ.-мат. наук: 01.01.07 - «Вычислительная математика» / Г.М. Кобельков. - М.: Изд-во МГУ, 1975. - 104 с.

2 Фикера Г. Теоремы существования в теории упругости / Г. Фикера. - М.: Мир, 1974. - 159 с.

3 Ладыженская О.А. О некоторых задачах векторного анализа и обобщенных постановках краевых задач для уравнения Навье-Стокса / О.А. Ладыженская, В.А. Солонников // Записки научного семинара ЛОМИ, 1976. - Т. 59. - С. 81-116.

4 Ладыженская О.А. Линейные и квазилинейные уравнения эллиптического типа / О.А. Ладыженская, Н.Н. Уральцева. - М.: Наука, 1973. - С. 120.

5 Степаненко B.М. Аппроксимация решения задачи теории упругости для несжимаемого материала / В.М. Степаненко // Сборник численных методов механики сплошной среды. - 1978. - Т. 9, № 6. - C. $136-145$.

М.М. Букенов, Д.К. Қойкелова

\title{
Статикалық қысылмайтын ортаны модельдеу
}

Мақалада Гук заңымен серпімділік теориясының статикалық есебін шешу арқылы Стокстың статикалық есебінің шешімін математикалық моделдеу қарастырылған. Асимптотика кезінде осы міндеттерді шешу жақындығының бағасы алынды, атап айтқанда $\lambda \rightarrow \infty$, бұл жағдайда Пуассон коэффициенті 0,5-ке ұмтылады, бұл қысылмайтын ортаға сәйкес келеді. Одан әрі жұмыста қарастырылған есептер шешімдерінің жақындығын бағалау $1 / \lambda$ ретімен жақсартылмайтын болып табылатыны дәлелденді. Бұл серпімділік теориясының статикалық есебі үшін бұрын айырымдық схемаларды қолдануға мүмкіндік береді, жақындатылған тордың жүйелілігіне Стокстың статикалық есебін шешу әдісі алынды.

Kiлm сөздер: қысылмайтын орта, Гук заңы, кернеу, деформация, орын ауыстыру, Ламе коэффициенттері, Стокс есебі, серпімділік теориясы, тепе-теңдік теңдеуі, бір байланысты облыс.

\author{
М.М. Букенов, Д.К. Койкелова
}

\section{Моделирование статической несжимаемой среды}

В статье рассмотрено математическое моделирование решения статической задачи Стокса с помощью решения статической задачи теории упругости с законом Гука. Получены оценки близости решений этих задач при асимптотике, а именно когда $\lambda \rightarrow \infty$, в этом случае коэффициент Пуассона стремится к 0,5 , что соответствует несжимаемой среде. Далее в работе доказано, что оценка близости решений рассмотренных задач является неулучшаемой по порядку $1 / \lambda$. Это позволяет использовать ранее неисследованные разностные схемы для статической задачи теории упругости, как приближенный получен метод решения статической задачи Стокса на последовательности сеток.

Ключевые слова: несжимаемая среда, закон Гука, напряжения, деформации, перемещения, коэффициенты Ламе, задача Стокса, теория упругости, уравнение равновесия, односвязная область.

\section{References}

1 Kobelkov, G.M. (1975). Chislennoe reshenie nekotorykh zadach teorii upruhosti [Numerical solution of some problems of the theory of elasticity]. Candidate's thesis. Moscow: Izdatelstvo MHU [in Russian].

2 Fickera, G. (1974). Teoremy sushchestvovaniia v teorii upruhosti [The existence theorems in the theory of elasticity]. Moscow: Mir [in Russian]. 
3 Ladyzhenskaya, O.A, \& Solonnikov, V.A. (1976). O nekotorykh zadachakh vektornoho analiza i obobshchennykh postanovkakh kraevykh zadach dlia uravneniia Nave-Stoksa [On some problems of vector analysis and generalized formulations of boundary value problems for the Navier-Stokes equation]. Zapiski nauchnoho seminara LOMI - Notes of the LOMI scientific seminar, Vol. 59, 81-116 [in Russian].

4 Ladyzhenskaya, O.A., \& Uraltseva, N.N. (1973). Lineinye kvazilineinye uravneniia ellipticheskoho tipa [Linear and quasilinear equations of elliptic type]. Moscow: Nauka [in Russian].

5 Stepanenko, V.M. (1978). Approksimatsiia resheniia zadachi teorii upruhosti dlia neszhimaiemoho materiala [Approximation of the solution of the problem of the theory of elasticity for incompressible material]. Sbornik chislennykh metodov mekhaniki sploshnoi sredy - Collection of Numerical Methods of continuum mechanics, Vol. 9, 6, 136-145 [in Russian]. 